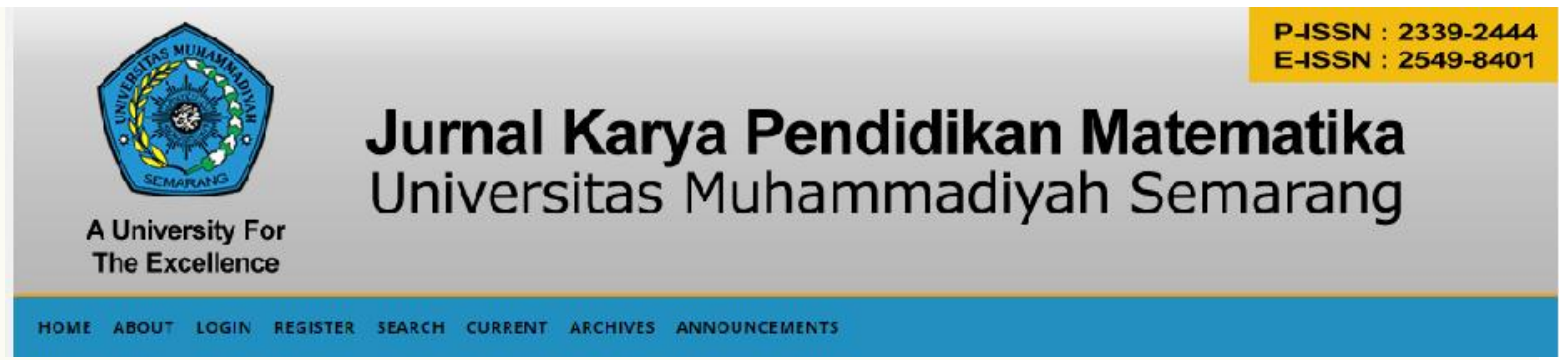

\title{
Perlukah Microteaching?-Representasi Kompetensi Profesional Mahasiswa Calon Guru Menggunakan Dokumen CoRe dan PaP-eR
}

Oleh: Andari Puji Astuti ${ }^{1)}$, Abdul Aziz ${ }^{2)}$, Sri Susilogati Sumarti ${ }^{3)}$, Dwi Anggani Linggar Bharati ${ }^{4)}$ andaripujiastuti@gmail.com,abdulazizrbg@gmail.com,susilogati@yahoo.com,dwi_anggani@yahoo.com

Universitas Muhammadiyah Semarang ${ }^{1,2)}$, Universitas Negeri Semarang ${ }^{3,4)}$

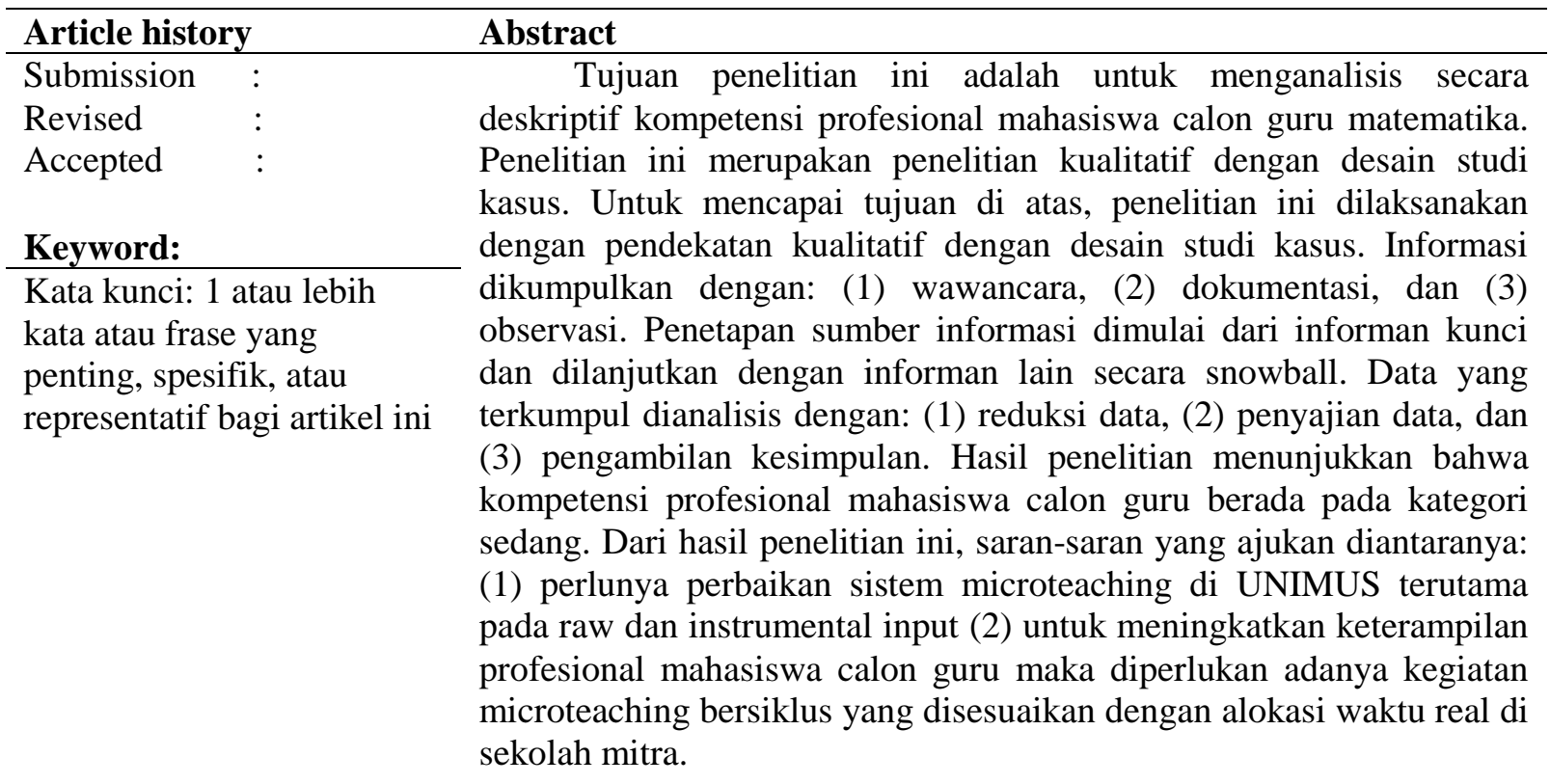

\section{Pendahuluan}

Generasi pembelajar abad 21 dikenal sebagai generasi Z. Generasi ini memiliki karakteristik yang berbeda. Generasi pembelajar 21 adalah peserta didik yang Generasi abad 21 memiliki ciri-ciri multitasking, multimedia, dan online info searching. Untuk itu, perlu dipersiapkan pembelajaran yang sesuai dengan karakteristik tersebut. Kegiatan belajar mengajar adalah bagian terpenting dari rangkaian panjang proses pendidikan di Indonesia. Inti dari kegiatan belajar mengajar ini ada pada aktor utamanya 
yaitu pendidik. Menurut hasil penelitian di Eropa () guru yang baik memiliki kriteria sebagai berikut: (1) expert dalam melaksanakan berbagai macam metode mengajar; (2) dapat melakukan berbagai variasi model pembelajaran sesuai dengan kebutuhan peserta didik; (3) memiliki pengetahuan tentang materi yang baik; (4) mampu memberikan informasi pengetahuan terbaru; (5) memberikan feedback yang baik dalam pembelajaran di kelas; (6) Mampu menggunakan berbagai macam metode penilaian hasil belajar; (7) Mampu mengembangkan bahan ajar atau materi ajar; (8) mampu bekerjasama dengan guru lain; (9) guru yang memiliki toleransi atau perilaku baik. Sedangkan tantangan guru abad 21 menurut Susanto (2010) adalah: (1). Guru harus mengajar di masyarakat yang memiliki beragam budaya dengan kompetensi multi bahasa.; (2) Guru harus mampu mengajar untuk mengkonstruksi makna (konsep); (3). Guru harus mampu mengajar untuk pembelajaran aktif; (4). Guru harus mampu mengajar dan menguasai teknologi; (5). Guru harus mampu mengajar dengan pandangan baru mengenai pengetahuan terbaru; (6). Teaching and choice, mengajar dan pilihan. (7). Guru harus mampu mengajar dan akuntabilitas. Untuk itu guru harus memiliki kompetensi yang diamanatkan oleh Undang- undang.

Kompetensi menurut Musfah (2011) adalah kemampuan seseorang yang meliputi pengetahuan, keterampilan, dan sikap yang dapat diwujudkan dalam hasil kerja nyata yang bermanfaat bagi diri sendiri dan lingkungannya. Sehingga kompetensi guru dapat diartikan sebagai kemampuan seorang guru yang meliputi pengetahuan, keterampilan, dan sikap yang dapat diwujudkan dalam hasil kerja nyata yang bermanfaat bagi diri sendiri dan lingkungannya UU RI Nomor 14 Tahun 2005 pasal 8 menyebutkan bahwa guru wajib memiliki kualifikasi akademik, kompetensi, sertifikat pendidik, sehat jasmani dan rohani, serta memiliki kemampuan untuk mewujudkan tujuan pendidikan nasional. Kompetensi yang dimaksud dalam pasal 8 adalah kompetensi pedagogik, kompetensi kepribadian, kompetensi sosial, dan kompetensi profesional yang diperoleh melalui pendidikan profesi. Kompetensi-kompetensi tersebut harus dimiliki oleh seorang guru agar dapat menjadi guru yang profesional.

Kompetensi profesional adalah kemampuan penguasaan materi pembelajaran secara luas dan mendalam yang memungkinkan guru untuk membimbing peserta didik menguasai pengetahuan atau keterampilan secara optimal, sehingga dapat memenuhi standar kompetensi yang telah ditetapkan dalam Standar Pendidikan Nasional" (Payong, 2011).

Kompetensi profesional adalah seperangkat kemampuan yang harus dimiliki seorang guru agar dapat melaksanakan tugas mengajarnya dengan berhasil" Uno (2010). Menurut Usman (2000) guru yang memiliki kompetensi profesional akan lebih mampu menciptakan lingkungan belajar yang efektif dan lebih mampu mengelola kelasnya sehingga peserta didik dapat mencapai hasil belajar optimal.

Untuk dapat meghasilkan kompetensi profesional guru, Universitas Muhammadiyah Semarang sebagai salah satu LPTK memilliki mata kuliah pratik kependidikan seperti Microteaching, Magang Kependidikan 1, 2 dan 3. Dalam mempersiapan calon guru profesional maka salah satu mata kuliah praktik mengajar yang pertama di lakukan adalah melalui kegiatan microteaching. Seberapa penting kegiatan microteaching dalam mempersiapkan calon guru profesional menjadi rumusan permasalahan dalam penulisan artikel ilmiah ini.

\section{Metode Penelitian}

Jenis Penelitian

Penelitian ini menggunakan pendekatan kualitatif studi kasus

\section{Waktu dan Tempat Penelitian}

Khususnya untuk penelitian kualitatif, waktu penelitian dilaksanakan pada bulan Januari- September 2018 di kota Semarang.

Target/Subjek Penelitian

Target/subjek penelitian adalah mahasiswa pendidikan matematika semester enam tahun ajaran 2017/2018 yang mengambil mata kuliah microteaching

Prosedur

Prosedur yang dilakukan pada penelitian ini dilakukan melalui pembentukan team teaching untuk melakukan perbaikan pada pembelajaran matematika di mata kuliah microteaching dengan model PDSA Cycle. PDSA Cycle terdiri dari Plan, Do, Study, dan Act yang berkelanjutan sebagaimana digambarkan pada Gambar 3.1. 


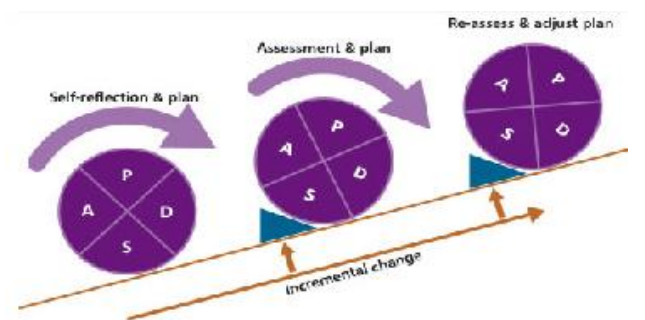

Gambar 3.1. Desain Penelitian dengan Model PDSA Cycle. (SumberAtweh, 2003)

Tabel 3.2 Rincian Prosedur Kegiatan
Data, Intrumen, dan Teknik Pengumpulan Data

Beberapa jenis instrumen yang digunakan dapat dilihat penjabarannya pada Tabel 3

Teknik Analisis data yang digunakan dalam penelitian ini adalah analisis hubungan kausal. Penyajian data dengan menggunakan jaringan kausal merupakan gambar inferensial yang telah disingkat yang mengorganisasikan data kajian dalam cara yang koheren. Sajian data ini mengambarkan alur hubungan-hubungan yang bersifat menentukan dan bukan semata-mata korelasional.

Standar yang digunakan dalam penelitian ini adalah praxis, trustworthiness, dan crystallisation. Praxis merupakan suatu cara

\begin{tabular}{|c|c|c|}
\hline \multicolumn{2}{|c|}{ Prosedur Penelitian } & Aktivitas \\
\hline PLAN & $\begin{array}{l}\text { Merencanakan setting } \\
\text { pembelajaran berupa } \\
\text { reduksi dokumen } \\
\text { CoRe yang akan } \\
\text { diterapkan pada } \\
\text { kegiatan } \\
\text { microteaching } \\
\text { Pemetaan materi } \\
\text { matematika di tingkat } \\
\text { SMA yang yang akan } \\
\text { disampaikan selama } \\
\text { kegiatan } \\
\text { microteaching. }\end{array}$ & $\begin{array}{l}\text { Pengumpulan } \\
\text { data melalui } \\
\text { aktivitas } \\
\text { koordinasi } \\
\text { dengan } \\
\text { Mahasiswa } \\
\text { Setting } \\
\text { pembelajaran } \\
\text { telah } \\
\text { didiskusikan } \\
\text { dan diwujudkan } \\
\text { melalui } \\
\text { dokumen } \\
\text { CoRe. }\end{array}$ \\
\hline$D O$ & $\begin{array}{l}\text { Pelaksanaan } \\
\text { Pembelajaran Kelas } \\
\text { menggunakan } \\
\text { dokumen CoRe yang } \\
\text { telah dikembangkan } \\
\text { dan dijabarkan dalam } \\
\text { RPP di kelas } \\
\text { microteaching }\end{array}$ & $\begin{array}{l}\text { Pengumpulan } \\
\text { data }\end{array}$ \\
\hline STUDY & $\begin{array}{l}\text { Review hasil kegiatan } \\
\text { pada mata kuliah } \\
\text { microteching melalui } \\
P a P-e R \text { yang } \\
\text { diperoleh. }\end{array}$ & $\begin{array}{l}\text { Pengumpulan } \\
\text { data dan } \\
\text { analisis data, } \\
\text { serta } \\
\text { mendiagnosa } \\
\text { hasil. }\end{array}$ \\
\hline$A C T$ & $\begin{array}{l}\text { Proses perbaikan dan } \\
\text { simpulan hasil } \\
\text { penelitian untuk } \\
\text { menuju penelitian }\end{array}$ & $\begin{array}{l}\text { Pengumpulan } \\
\text { data dan } \\
\text { pembuatan } \\
\text { laporan }\end{array}$ \\
\hline
\end{tabular}
di mana peneliti berusaha menstimulus pembaca agar dengan sengaja mengubah praktik. Trustworthiness merupakan kriteria yang sama dengan valid, reliabel, dan objektif dalam penelitian kuantitatif (Guba \& Lincoln, 1988). Menurut Guba and Lincoln (1988), hal ini dapat dilakukan melalui credibility (via member checking), transferability (via thick description), dependability (via emergence), and confirmability (via data audit trail). Selanjutnya pada penelitian ini, peneliti akan menganalisa pencapaian yang dihasilkan dalam berbagai perspective, hal ini didukung oleh Denzin dan Lincoln (2008), yang menyatakan bahwa dalam proses crystallization peneliti dapat menganalisa situasi yang sama dalam perspektif yang berbeda. Selain itu, dilakukan pula teknik triangulasi sebagai quality standards pada kasus-kasus tertentu.

Analisis Data

Data yang terkumpul dianalisis dengan: (1) reduksi data, (2) penyajian data, dan (3) pengambilan kesimpulan.

\section{Hasil Penelitian dan Pembahasan \\ 1. Pembuatan CoRe dan RPP.}

Pada tahap ini para informan diminta untuk membuat CoRe. CoRe ini berisi delapan pertanyaan yang dapat menggali pengetahuan tentang Pengetahuan Kesulitan Belajar Siswa, Orientasi Mengajar Mahasiswa Calon guru dan Kemampuan mengajar mahasiswa calon guru matematika. Sebagai contoh CoRe yang dibuat 
Jurnal Karya Pendidikan Matematika Vol 5No 2 Tahun 2018 E ISSN : 2549 - 8401 P ISSN : 2339-2444 oleh mahasiswa, dapat dilihat pada Tabel 1. berikut. 


\begin{tabular}{|c|c|c|c|c|}
\hline \multirow[t]{5}{*}{ No. } & \multirow{2}{*}{\multicolumn{4}{|c|}{$\begin{array}{l}\text { Konsep Sains : PROGRAM LINIER (Fakta, Konsep, Prosedur, Representatif) } \\
\text { Kelas/Semester } \text { : XI / SEMESTER 1 }\end{array}$}} \\
\hline & & & & \\
\hline & \multicolumn{4}{|c|}{ Pengampu : Arum Cahyanining } \\
\hline & \multicolumn{4}{|c|}{ Sumber : Matematika; Buku Guru (Kementrian Pendidikan dan Kebudayaan) } \\
\hline & Pertanyaan & $\begin{array}{l}\text { Model Matematika (Fakta dan } \\
\text { Konsep) }\end{array}$ & $\begin{array}{l}\text { Program Linier dengan Metode Grafik } \\
\text { (Prosedur) }\end{array}$ & $\begin{array}{l}\text { Daerah Bersih dan Garis Selidik } \\
\text { (Representatif dalam perhitungan harga } \\
\text { obat dalam bidang Kesehatan) }\end{array}$ \\
\hline 1 & $\begin{array}{l}\text { Apa yang Anda harapkan } \\
\text { dipelajari oleh siswa? }\end{array}$ & $\begin{array}{l}\text { - Menemukan konsep model } \\
\text { matematika }\end{array}$ & $\begin{array}{l}\text { - Menyajikan program linier dengan metode } \\
\text { grafik }\end{array}$ & $\begin{array}{l}\text { - Mengetahui daerha bersih dan garis } \\
\text { selidik dalam program linier }\end{array}$ \\
\hline 2 & $\begin{array}{l}\text { Mengapa hal itu penting } \\
\text { untuk siswa ketahui? }\end{array}$ & $\begin{array}{ll}\text { - } & \text { Siswa dapat menemukan } \\
\text { konsep model matematika } \\
\text { melalui permasalahan nyata } \\
\text { yang dikaitkan dalm kehidupan } \\
\text { sehari-hari }\end{array}$ & $\begin{array}{llll}\text { - } & \text { Siswa dapat menyajikan program linier } \\
\text { dengan metode grafik }\end{array}$ & $\begin{array}{l}\text { Siswa dapat mengetahui daerah bersih } \\
\text { dan garis selidik dalam program linier }\end{array}$ \\
\hline 3 & $\begin{array}{l}\text { Prosedur-prosedur dalam } \\
\text { mengajarkan (dan alasan } \\
\text { penggunaanya kaitannya } \\
\text { dengan ide yang ada) }\end{array}$ & 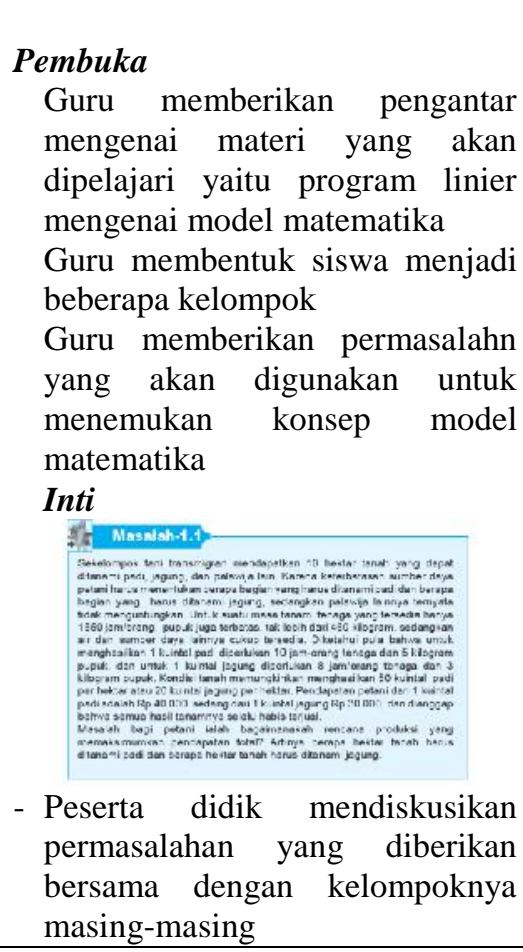 & 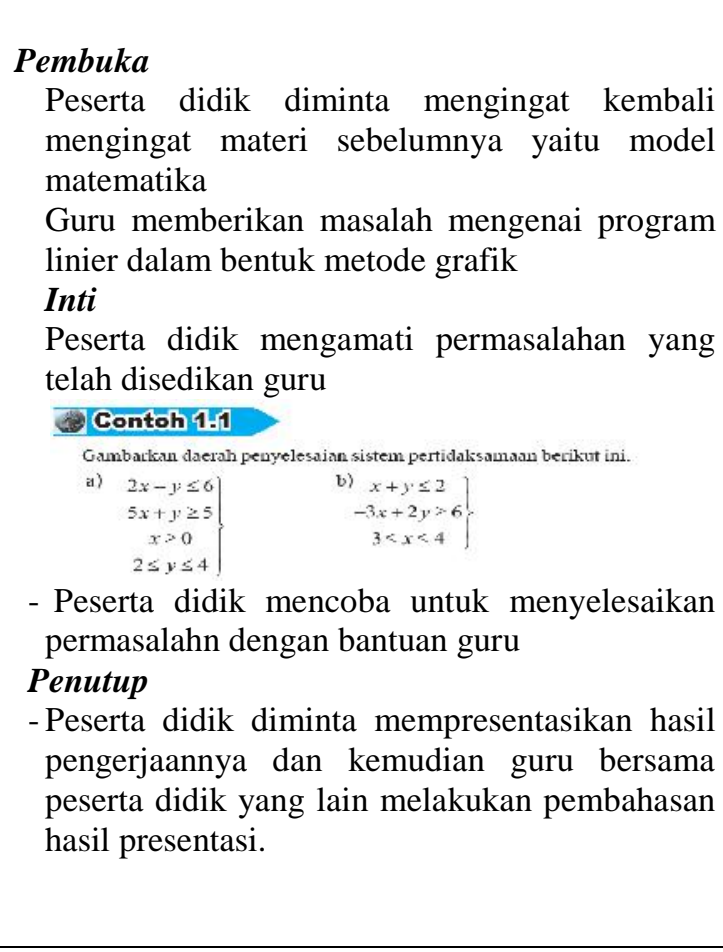 & 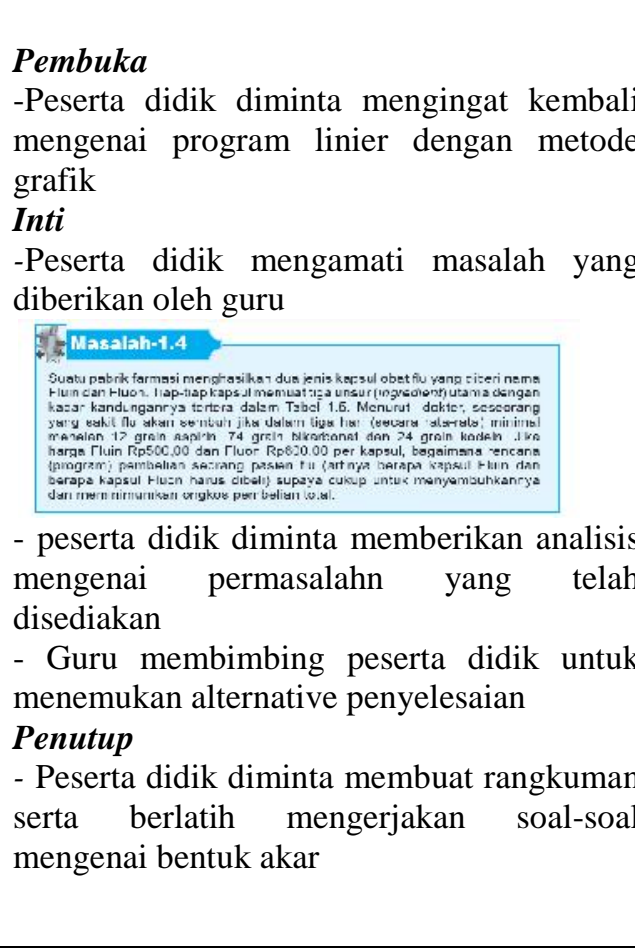 \\
\hline
\end{tabular}




\begin{tabular}{|c|c|c|c|c|}
\hline & & $\begin{array}{l}\text { - Guru membimbing jalannya } \\
\text { diskusi kelompok yang dilakukan } \\
\text { oleh siswa } \\
\text { - Setiap kelompok mewakilkan } \\
\text { satu anggota kelompoknya untuk } \\
\text { mempresentasikan hasil diskusi } \\
\text { kelompok } \\
\text { Penutup } \\
\text { - Peserta didik dan guru bersama- } \\
\text { sama menyimpulkan materi } \\
\text { konsep model matematika }\end{array}$ & & \\
\hline 4 & $\begin{array}{l}\text { Cara spesifik untuk } \\
\text { memastikan pemahaman } \\
\text { atau kebingungan siswa } \\
\text { mengenai materi }\end{array}$ & $\begin{array}{l}\text { - Memberikan soal-soal evaluasi } \\
\text { mengenai konsep model } \\
\text { matematika dalam soal nyata } \\
\text { dikehidupan nyata }\end{array}$ & $\begin{array}{l}\text { Memberikan prestest dan postest terkait } \\
\text { mataeri yang akan dipelajari yaitu program } \\
\text { linier dengan metode grafik }\end{array}$ & $\begin{array}{l}\text { - Bertanya disela-sela pembelajaran untuk } \\
\text { mamastikan siswa telah paham materi } \\
\text { yang dipelajari yaitu mengenai daerah } \\
\text { bersih dan garis selidik }\end{array}$ \\
\hline 5 & $\begin{array}{l}\text { Apa lagi yang anda ketahui } \\
\text { tentang konsep ini (Apa } \\
\text { yang tidak Anda inginkan } \\
\text { untuk dipelajari oleh siswa } \\
\text { terlebih dahulu saat ini?) }\end{array}$ & $\begin{array}{l}\text { - Model matematika dalam } \\
\text { bentuk grafik }\end{array}$ & - Daerah bersih dan daerah selidik & $\begin{array}{l}\text { - Aplikasian daerah bersih dan daerah } \\
\text { selidik selain didalam bidang ekonomi }\end{array}$ \\
\hline 6 & $\begin{array}{l}\text { Kesulitan-kesulitan/ } \\
\text { keterbatasan yang } \\
\text { berhubungan dengan } \\
\text { mengajarkan ide ini }\end{array}$ & $\begin{array}{l}\text { Membimbing peserta didik } \\
\text { dalam melakukan diskusi } \\
\text { dalam menemukan konsep } \\
\text { model matematika }\end{array}$ & $\begin{array}{l}\text { Menjelaskan peserta didik mengenai program } \\
\text { lnier dengan metode grafik }\end{array}$ & $\begin{array}{l}\text { - } \begin{array}{l}\text { Memahamkan siswa dalam menjelaskan } \\
\text { daerah bersih dan garis selidik }\end{array}\end{array}$ \\
\hline 7 & $\begin{array}{l}\text { Pengetahuan tentang } \\
\text { pemikiran siswa yang } \\
\text { mempengaruhi dalam } \\
\text { mengajarkan ide ini }\end{array}$ & $\begin{array}{l}\text { - Materi konsep model matematika } \\
\text { untuk menyajikan soal-soal dalam } \\
\text { keghidupan nyata dalam bentuk } \\
\text { matematika }\end{array}$ & $\begin{array}{l}\text { - Pemikiran siswa dapat menyelesaikan atau } \\
\text { menyajikan model matematika dalam bentuk } \\
\text { grafik }\end{array}$ & $\begin{array}{l}\text { - pemikiran bahwa siswa akan mengetahui } \\
\text { apa yang dimaksud dengan daerah bersih } \\
\text { dan garis selidik dan bagaimana } \\
\text { menyelesaikan soal-soal tersebut berkaitan } \\
\text { dengan kehidupan nyata }\end{array}$ \\
\hline 8 & $\begin{array}{l}\text { Faktor-faktor lainnya yang } \\
\text { mempengaruhi pengajaran } \\
\text { ide ini }\end{array}$ & $\begin{array}{l}\text { - Keterbatasan pengetahuan siswa } \\
\text { mengenai konsep model } \\
\text { matematika }\end{array}$ & $\begin{array}{l}\text { Keterbatasan pemberian soal latian mengenai } \\
\text { program linier dengan metode grafik }\end{array}$ & $\begin{array}{l}\text { Keterbatasan waktu dalam pembelajaran } \\
\text { ini dalam membrerikan pengajaran } \\
\text { mengenai daerah bersih dan garis } \\
\text { selidik }\end{array}$ \\
\hline
\end{tabular}

Tabel 1. Contoh dokumen CoRe mahasiswa caon gu 
Content of Repesentation (CoRe) menurut berbagai penelitian dapat mengungkapkan kesiapan mahasiswa calon guru dalam menngajar. (Mulhall, Loughran, dan Berry,. 2003). Di Indonesia sendiri CoRe tidak dibuat oleh guru ataupun mahasiswa calon guru. Para pendidik secara administratif dibebani merancang RPP sebagai bagian dari skenario pembelajaran. Perbedaan dasar antara RPP dengan CoRe adalah, dalam CoRe akan terungkap bagaimana kreativitas guru dalam mengajar dengan munculnya berbagai macam ide pembelajaran, bagaimana para guru dapat mengenali kesulitasn- kesulitan yang mungkin akan ditemui oleh para peserta didik, piramida pengetahuan para peserta didik mulai dari pengetahuan dasar peserta didik yang mempengaruhi mereka dalam mempelajari suatu konsep dan faktor- faktor apa saja yang mempengaruhi dalam mempengaruhi kegiatan mengajar dan lain sebagainya. Hal ini berbeda dengnformat RPP yang diminta oleh para pengambil kebijakan di bidang pendidikan Indonesia. RPP secara garis besar berisi tentang Standar kompetensi, Kompetensi dasar, tujuan dan indikator pembelajaran, materi ajar, metode mengajar, langkah- langkah pembelajaran dan penilaian hasil belajar. RPP lebih kepada skenario pembelajaran. RPP dapat terlaksana atau tidak dapat dievaluasi setelah pembelajaran selesai. Kemampuan melaksanakan pembelajaran ini adalah bagian dari kompetensi profesional guru dalam pengelolaan kelas. Dalam penelitian ini, mahasiswa calon guru diminta membuat CoRe terlebih dahulu sebelum mereka membuat RPP. Dari CoRe yang dikembangkan oleh mahasiswa calon guru, kemudian peneliti merepresentsikan kemampuan profesional mahasiswa calon guru secara teori. Hasil representasi menunjukkan bahwa kemampuan mahasiswa caoln guru dalam mengenali kesulitan belajar peserta didik sudah baik, namun mahasiswa calon guru memiliki kreativitas yang berada pada kategori sedang pada pengembangan ide/ gagasan dalam menjelaskan suatu topik.

(2) tahapan pelaksanaan microteaching.

Pada tahap kedua ini, mahasiswa calon guru mempraktikkan CoRe dan RPP yang mereka buat.

Microteaching atau pembelajaran micro merupakan cara latihan praktek mengajar yang dilakukan dalam pembelajaran micro untuk membentuk dan mengembangkan keterampilan mengajar mahasiswa calon guru. Micro yang dimaksud dalam microteaching ini adalah penyederhanaan jumlah peserta didik, waktu, bahas mengajar dan atau keterampilan dasar mengajar tertentu. Perbedaan mengajar sebenarnya dan pengajaran micro dapat dilihat pada tabel 3.1

Tabel 3.1 PerbedaanPembelajaran Biasa dan Mikro

\begin{tabular}{|l|l|l|}
\hline No. & Pembelajaran Biasa & $\begin{array}{l}\text { Pembelajaran } \\
\text { Mikro }\end{array}$ \\
\hline 1 & $\begin{array}{l}\text { Waktu } \\
\text { pembelajaran } \\
\text { antara 45 s.d } \\
90 \text { menit }\end{array}$ & $\begin{array}{l}\text { Waktu } \\
\text { pembelajaran } \\
\text { antara 30 s.d } \\
40 \text { menit siswa }\end{array}$ \\
\hline 2 & $\begin{array}{l}\text { Jumlah siswa } \\
\text { antara 30 s.d 35 }\end{array}$ & $\begin{array}{l}\text { Jumlah } \\
\text { kurang dari 20 }\end{array}$ \\
\hline 3 & $\begin{array}{l}\text { Materi } \\
\text { pembelajaran luas }\end{array}$ & $\begin{array}{l}\text { Materi } \\
\text { pembelajaran } \\
\text { terbatas }\end{array}$ \\
\hline 4 & $\begin{array}{l}\text { Keterampilan } \\
\text { mengajar } \\
\text { terintegrasi }\end{array}$ & $\begin{array}{l}\text { Keterampilan } \\
\text { mengajar } \\
\text { terbatas }\end{array}$ \\
\hline
\end{tabular}

Pendidikan Matematika UNIMUS melakukan penyederhanaan waktu dan bahan mengajar dalam praktik microteachingnya. Kegiatan microteaching hanya dapat dilakukan oleh mahasiswa pendidikan matematika sebanyak satu kali di setiap semesternya. Hal ini dikarenakan adanya keterbatasan ruang dan waktu yang tersedia di fakultas MIPA.

Berikut adalah aspek kompetensi profesional guru yang dinilai menggunakan dokumen $\mathrm{CoRe}$ dan RPP dari kegiatan Microtaching: (1) Penguasaan Materi; (2) Kemampuan Membuka Pelajaran; (3) Kemampuan Bertanya; (4) Kemampuan mengadakan variasi pembelajaran; (5) Kejelasan dan penyajian materi; (6) Kemampuan mengelola kelas; (7) Kemampuan menutup pelajaran; (8) Ketepatan antara waktu dan materi pelajaran.

Penilaian yang digunakan adalah metode triangulasi dari mahasiswa praktikan, mahasiswa yang berperan sebagai peserta didik dan dosen pengampu mata kuliah microteaching. Hasil penilaian kompetensi profesional mahasiswa calon guru dapat dilihat pada tabel 3.2. 
Tabel 3.2 Deskripsi Kompetensi Profesional Mahasiswa calon Guru Pendidikan Matematika

\begin{tabular}{|c|c|c|}
\hline No. & Aspek yang dinilai & Deskripsi \\
\hline 1. & Penguasaan materi & $\begin{array}{l}\text { Mahasiswa calon guru telah menguasai materi yang } \\
\text { akan diajarkan. Sebelum mengajar, Mahasiswa calon } \\
\text { guru memantapkan materi dengan membaca berbagai } \\
\text { buku untuk referensi dan memantapkan materi yang } \\
\text { akan diajarkan dengan berkonsultasi ke dosen. }\end{array}$ \\
\hline 2. & Kemampuan membuka pelajaran & $\begin{array}{l}\text { Kemampuan membuka pelajaran sebagian mahasiswa } \\
\text { sudah baik. Mahasiswa calon guru mengucapkan } \\
\text { salam dan mempresensi siswa serta memberi apersepsi } \\
\text { terkait materi yang akan diajarkan. Namun ada } \\
\text { beberapa mahasiswa yang mengalami kesulitan. } \\
\text { Kegiatan membuka pelajaran yang mahasiswa lakukan } \\
\text { masih kurang maksimal dalam mengarahkan dan } \\
\text { mempersiapkan siswa mengikuti pelajaran dengan } \\
\text { baik, hal ini disebabkan ketika membuka pelajaran } \\
\text { dengan menggunakan video motivasi mahasiswa } \\
\text { kurang mampu mengaitkan antara video tersebut } \\
\text { dengan materi yang mereka ajarkan }\end{array}$ \\
\hline 3. & Kemampuan bertanya & $\begin{array}{l}\text { Mahasiswa calon guru belum semua terlihat } \\
\text { menanyakan pertanyaan-pertanyaan } \\
\text { terkait materi yang akan diajarkan. }\end{array}$ \\
\hline 4. & $\begin{array}{l}\text { Kemampuan mengadakan variasi } \\
\text { pembelajaran }\end{array}$ & $\begin{array}{l}\text { Mahasiswa calon guru mampu mengadakan variasi } \\
\text { pembelajaran dengan menggunakan berbagai model } \\
\text { pembelajaran yang variatif dan disesuaikan dengan } \\
\text { pendekatan sainstifik. }\end{array}$ \\
\hline 5. & Kejelasan dan penyajian materi & $\begin{array}{l}\text { Penyajian materi dibantu menggunakan powerpoint } \\
\text { dan media pembelajaran lainnya seperti software dan } \\
\text { video. Penyampaian materi sebagian mahasiswa sudah } \\
\text { sangat baik. Namun, masih ada mahaiswa yang } \\
\text { memiliki kesulitan dalam menjelaskan materi. }\end{array}$ \\
\hline 6. & Kemampuan mengelola kelas & $\begin{array}{l}\text { Mahasiswa calon guru belum dapat menggunakan } \\
\text { waktu dengan baik dalam pembelajaran seperti diskusi, } \\
\text { tanya jawab, dan tugas. Saat praktik beberapa } \\
\text { mahasiswa, Kelas belum dapat terkondisi dengan baik } \\
\text { sehingga proses pembelajaran belum dapat berjalan } \\
\text { dengan lancar. }\end{array}$ \\
\hline 7. & Kemampuan menutup pelajaran & $\begin{array}{l}\text { Kegiatan menutup pelajaran dilakukan } \\
\text { menyimpulkan materi apa saja yang } \\
\text { disampaikan, merefleksi nilai-nilai sikap selama } \\
\text { kegiatan pembelajaran berlangsung, memberi tugas } \\
\text { membaca materi yang akan diberikan di pertemuan } \\
\text { yang akan datang, dan diakhiri dengan salam penutup. } \\
\text { Kemampuan menutup pelajaran sudah baik }\end{array}$ \\
\hline 8. & $\begin{array}{l}\text { Ketepatan antara waktu dan } \\
\text { materi pelajaran }\end{array}$ & $\begin{array}{l}\text { Ketepatan antara waktu dan materi pelajaran belum } \\
\text { dapat terkoordinir dengan baik. Mahasiswa calon guru } \\
\text { belum mampu memanajemen waktu selama } \\
\text { pembelajaran dengan baik karena waktu yang } \\
\text { digunakan sangat terbatas sehingga pelajaran belum } \\
\text { dapat tersampaikan secara keseluruhan kepada peserta } \\
\text { didik. }\end{array}$ \\
\hline
\end{tabular}


Berdasarkan hasil observasi kompetensi profesional mahasiswa calon guru diatas, diketahui bahwa mahasiswa pendidikan matematika UNIMUS sudah memiliki kemampuan merencanakan dan mengelola proses pembelajaran di kelas. Namun, kelemahan mahasiswa calon guru matematika adalah kemampuan dalam mengelola waktu. Mahasiswa masih belum terbiasa memanajemen waktu real pembelajaran. Dari kasus yang telah dilaksanakan dikelas, untuk penguatan materi mahasiswa masih dapat belajar dari sesama mahasiswa maupun dari dosen. Namun, untuk keterampilan menggunakan waktu, perlu adanya kegiatan praktik mengajar yang dilaksanakan secara bersiklus. Dari temuan ini, maka kegiatan microteaching dan praktik di sekolah mitra/ magang sanngat dibutuhkan oleh mahasiswa pendidikan secara umum.

\section{Simpulan dan Saran}

Simpulan

Simpulan yang didapatkan dari penelitian ini adalah:

1. mahasiswa pendidikan matematika UNIMUS memiliki kompetensi profesional yang baik.

2. Keterampilan dasar mengajar yang perlu ditingkatkan adalah keterampilan manajemen waktu.

3. Pembelajaran microteaching dan kegiatan praktik mengajar sangat dibutuhkan oleh mahasiswa calon guru.

Saran

Saran-saran yang ajukan diantaranya: (1) perlunya perbaikan sistem microteaching di UNIMUS terutama pada raw dan instrumental input (2) untuk meningkatkan keterampilan profesional mahasiswa calon guru maka diperlukan adanya kegiatan microteaching bersiklus yang disesuaikan dengan alokasi waktu real di sekolah mitra.

\section{Ucapan Terima Kasih}

Penelitian ini seluruhnya didanai oleh Kemristek Dikti, dengan nomor kontrak penellitian 037/UNIMUS.J/PJ/PG/2018.

\section{Daftar Pustaka}

1. Atweh, B. dan Heirdsfiled, A. 2003. The Use Action Research for Professionalisation of Beginning Women Teachers as They Learn About Inclusive Mathematics. Dipublikasikan dalam Journal Mathematics Teacher Education and Development. Volume 5: 55-69.

2. Loughran,J., Mulhall, A., Berry, A. 2004. In Search of Pedagogical Content Knowlegde in Science Developing Ways of Articulating and Documenting Professional Practice. Journal of Research in Science Teaching. Volume 41 (4): 370-391.

3. Mulhall, A., Loughran, J., Berry, A. 2003. Frameworks for Representing Science Teacher Pedagogical Content Knowledge. Journal of Asia- Pacific Forum on Science Learning and Teaching. Volume 4(2): 1-25.

4. Uno, H.M. 2010. Profesi Kependidikan: Problematika, Solusi, dan Reformasi Kencana.Pendidikan di Indonesia. Jakarta: PT. Bumi Aksara.

5. Usman, M.U. 2011. Menjadi Guru Profesional. Bandung: PT. Remaja Rosdakarya. 